\title{
A Reflection on the Effects of Mother-Tongue Hermeneutics on Christianity: An Entrepreneurial Dimension for Propagating the Christian Faith
}

\author{
Livingstone Yao Torsu ${ }^{1}$ \\ 1 Department of Theology, Heritage Christian College, Accra- Ghana.
}

\begin{abstract}
This study uses the historical method to display the importance of Mother tongue hermeneutics and its contribution to the viability of Christianity, particularly in Ghana. Though the enterprise of translation is primitive Mother-Tongue Hermeneutics is a new development in theological studies. Its focus is to make the Bible easy for everyone to read and understand in his or her own mother-tongue. Thus, it is an enterprise that conveys Biblical concepts from the original languages (Hebrew and Greek) of the Judeo-Christian Bible into varied local languages. The historical method helps to trace the historical context of an event of mother tongue hermeneutics and its impact on society. Mothertongue hermeneutics has birthed several indigenous churches as well as many preachers of the gospel today. It makes Christianity in Africa particularly Ghana viable.
\end{abstract}

Keywords: Entrepreneurship, mother-tongue hermeneutics, inculturation, libration.

(C) 2021 The Author. Published and Maintained by Noyam Publishers.

This is an open access article under the CCBY license (http://creativecommons.org/licenses/by/4.0/).

\section{INTRODUCTION}

The work of mother-tongue hermeneutics can be located under the enterprise known as entrepreneurship. It is a new development which has emerged in the area of Bible translation 'to give Ghanaians/Africans the opportunity to interpret Scripture from their own world-view." ${ }^{1}$ Entrepreneurship is 'discovery and exploitation of opportunities to the creation of enterprise. It includes behavior that manages to combine innovation, risk-taking and pro-activeness. ${ }^{2}$ It 'emphasizes on exploration, search and innovation, as opposed to the exploitation of business opportunities pertaining to managers.' 3 Thus, all that entrepreneurship sets out to do is to explore opportunities to make something new for the benefit of the society. Which is not different from the purpose of mother-tongue hermeneutics. As Ekem puts it, 'mother-tongue hermeneutics is a context-sensitive interpretation ${ }^{4}$ which will end up 'providing study bibles and commentaries that clearly articulate theological, linguistic and anthropological issues in the people's own local languages. ${ }^{5}$ This trend seems to be the offshoot of earlier procedures devised by the early scholars in the Africa continent. It is observed that 'Africa can rightly be referred to as the cradle of systematic biblical interpretation in Christianity. ${ }^{6}$ Thus, 'the earliest of such an attempt can be traced to the city of Alexandrian and to such names as Clement of Alexandria, Origin and others who lived and worked there. ${ }^{7}$

The relevance of mother-tongue cannot be underestimated because it "is the medium of our innermost feelings

\footnotetext{
Jonathan E. T. Kuwornu-Adjaottor Mother-Tongue Biblical Hermeneutics: A Current Trend in Biblical Studies in Ghana. Journal of Emerging Trends in Educational Research and Policy Studies 3 no.4 (2012), 577.

Danny Miller, The correlates of entrepreneurship in three types of firms. Management Science, 29, (1983):770-791.

3 Miller, The correlates of entrepreneurship in three types of firms. 770-791.

4 John D.K. Ekem, Priesthood in Context: A Study of Priesthood in Some Christian and Primal Communities of Ghana and its Relevance for Mother-Tongue Biblical Interpretation. (Accra: SonLife Press, 2008), 188

Ekem, Priesthood in Context, 188.

6 Justin S. Ukpong, Developments in Biblical interpretation in Africa: Historical and Hermeneutical directions. In Gerald O. West and Musa W. Dube eds. The Bible in Africa: Transactions, Trajectories and Trends (Leiden-Boston-Koln; Brill, 2000), 11.

Ukpong, Developments in Biblical interpretation in Africa, 11.
} 
and thought. ${ }^{8}$ For it is that native language into which one is born and in which one grows up. ${ }^{9}$ It is a person's first language as compared to other languages one might learn later in life, for instance, at school. It is also contested that 'a mother-tongue is not the same as a vernacular which is the common language of a region or group, no matter how naturally a person may be well vexed in such a language and its usage. ${ }^{10}$ It is different from the mother-tongue because it is a community or local language, unlike blood-related language which is acquired mostly from relatives. Mothertongue 'is a person's own native and indigenous language, very much intertwined with a person's identity; it confirms and affirms who a person is, where one comes from and one's sense of identity. ${ }^{11}$ This is suggested because a mothertongue is a blood-related language which has its source from relatives, it reflects the self-image of the user. It might be the reason why 'a mother-tongue is a repository of indigenous wisdom, knowledge, insight, science, theology and philosophy. It is in the mother-tongue that one thinks and dreams, before translating one's thoughts to other languages. Mother-tongue biblical studies are the scholarly engagement of the indigenous language translations of the Bible in order to understand what they say and mean to the readers. ${ }^{12}$ This, therefore, situates mother-tongue biblical studies within an academic context where it 'uses the mother-tongue Bibles - the translations of the Bible into such languages into which people are born and nurtured. ${ }^{13}$

\section{Relationship between Mother-Tongue Hermeneutics and Entrepreneurship}

By observation, the relationship between mother-tongue hermeneutics and entrepreneurship is displayed in the area of creativity because of the comment made by the proponents of this interpretation. Creativity is a process by which a symbolic domain in the culture is changed. New songs, new ideas, new machines are what creativity is about. ${ }^{14}$ Again it is maintained that creativity is the ability to make or otherwise bring into existence something new, whether a new solution to a problem, a new method or device, or a new artistic object or form. ${ }^{15}$ This creativity is what has been adopted by the translators by using local language and cultural artefacts to convey the meaning of original texts (Hebrew text and Greek text) to the local people. For instance, it is alleged that biblical scholars in Africa have been able to develop a parallel method of their own. The particular characteristic of this method is the concern to create an encounter between text and the African context. ${ }^{16}$ Just like what happens in entrepreneurship. It is argued that 'entrepreneurship means much more than starting a new business. It denotes the whole process whereby individuals become aware of the opportunities that exist to empower themselves, develop ideas, and take personal responsibility and initiative. ${ }^{17}$ Thus, the major factor in entrepreneurship is developing ideas to do something. Which therefore designates innovation as 'the tool of entrepreneurship. In addition, both innovation and entrepreneurship demand creativity. Entrepreneurship is, therefore, a key priority area with the potential to stimulate job and wealth creation innovatively and independently. ${ }^{18}$ Comparing the process and the motivation of both interpretation and entrepreneurship suggests that the link between them is the concept of developing ideas to do something new. In a broader sense, entrepreneurship helps young men and women develop new skills and experiences that can be applied to many other challenges in life. ${ }^{19}$

\section{The Need for Mother-Tongue Hermeneutics}

It is noted that 'religion permeates all aspects of African life with no conscious efforts made, even during the routines of life, to separate sacred from secular realities. ${ }^{20}$ This points out that African life cannot be meaningfully lived without the influence of religion. Therefore, it appears that 'life remains an integrated whole in the African imagination and so, in the missionary era, there were difficulties in coming to terms with the Christian faith that failed to respond to deep questions that Africans brought to the church. ${ }^{21}$ As a result of that, "the marginalization of experiential religion and the relegation of practical salvific needs to the backgrounds of church life led African Christians to take their religious destinies into their own hands. ${ }^{22}$ Bible translation is doubtlessly a very important component of the history of the

\footnotetext{
Reginald F. Amonoo,. Language and Nationhood: Reflections on Language Situations with Particular Reference to Ghana-The J. B. Danquah Memorial Lectures Series 19, February 1986. (Accra: Ghana Academy of Arts and Sciences, 1989).

9 Benhardt Y. Quarshie, "Doing Biblical Studies in the African Context - The Challenge of Mother-tongue Scriptures," Journal of African Christian Thought, 5, no 1, (2002): 4-14.

10 Kuwornu-Adjaottor, Mother-Tongue Biblical Hermeneutics, 575-579.

11 Kuwornu-Adjaottor, Mother-Tongue Biblical Hermeneutics, 575-579.

Kuwornu-Adjaottor, Mother-Tongue Biblical Hermeneutics. 575-579.

Kuwornu-Adjaottor, Mother-Tongue Biblical Hermeneutics, 575-579.

Friday O. Okpara, The Value of Creativity and Innovation in Entrepreneurship. Journal of Asia Entrepreneurship and Sustainability, 3, no. 2, (2007): 1.

Okpara, The Value of Creativity and Innovation in Entrepreneurship, 1.

Ukpong, Developments in Biblical interpretation in Africa, 12.

Okpara, The Value of Creativity and Innovation in Entrepreneurship, 1

Okpara, The Value of Creativity and Innovation in Entrepreneurship, 1.

Okpara, The Value of Creativity and Innovation in Entrepreneurship, 1.

Ekem, Priesthood in Context, 5.

Ekem, Priesthood in Context, 5.

Ekem, Priesthood in Context, 113
} 
founding, establishment, and growth of the church among the people concerned. ${ }^{23}$ Biblical traditionalism and literalism are still more marked in the independent churches and denominations rooted in the Pentecostal tradition, but similar currents are found among Catholics. ${ }^{24}$

\section{Effects of the Mother-Tongue on Christianity}

Dwelling on the existing research conducted in the field for evaluating the significant role mother-tongue hermeneutics has played since its inception provides formidable information to project its impact on Christianity particularly Africa for that matter Ghana. It has been revealed that Mother-tongue hermeneutics brought about the establishment of several indigenous churches as well as the development of many preachers of the gospel. It has caused the viability of Christianity in Africa particularly Ghana. Adopting and adapting the work of Clarke will be of great importance to this study because it points out that some of the effects of mother tongue hermeneutics in Christianity are obvious to observers. Clarke's work reveals that he engaged in this study by using an instrument like questionnaires to solicit views on the topic. He notes that 'in a questionnaire that was given out in 2001, that surveyed 2500 members of African Indigenous Christian (AIC) and 98 individual churches, to enquire as to how African Indigenous Christian(AIC) experienced Christ, ${ }^{25}$ noted that, the vernacular Bible emerged as a pivotal reference point in the development of African Indigenous Church(AIC) spirituality. ${ }^{26}$ Clarke adds that the survey which was conducted across the ten regions of Ghana indicated that $77 \%$ of respondents saw 'reading the Bible' as their primary means of experiencing the presence of Christ. The survey also noted that $90 \%$ of the churches surveyed read the Bible and conducted their services using their local vernacular. ${ }^{27}$ It has been convincingly argued by a number of African theologians and scholars of African religions that the main reason why the Bible gained such a strong footing among AICs is because of its accessibility and apprehension through the vernacular. ${ }^{28}$ It is also noted that the ability of African Christians to hear the gospel in their own language and to express in their own tongue the message presented to them, lies at the heart of indigenizing Christianity in the African setting. In this regard, language is not merely a social or psychological phenomenon, but a theological one as well. ${ }^{29} \mathrm{The}$ propagation of the Gospel has not only been a factor of change vis-à-vis the religio-cultural practices, it has also served as the preserver and the creator of cultures. The crucial test here is language. ${ }^{30}$ The emergence of non-western languages and culture "was a victory signal for history underdogs, and equally for the prospects of intercultural solidarity...we can overcome barriers of exclusion and suspicion only when we turn to the one God in our own idiom, for that idiom in its variety is what we all have in common as the ground of our concrete individuality. It is there that God will meet and not leave us. ${ }^{31}$ The discovery of the theological significance of the scriptures in African mother tongues is bringing a new excitement about exploring these other dimensions of the study of the scriptures. There is, first, a new awareness of the role of mother tongue scriptures in engaging with the religious and cultural worlds that provide the setting in which Christians and churches witness the gospel in the African context. ${ }^{32}$

\section{Some Products of Mother-Tongues}

Scholars to a large extent agree that the Septuagint was the first translation of the Jewish texts to serve Jewish Christians in the Greco-Roman diaspora in order to understand the message in the local language. This was followed by many local language Bibles, Commentaries, files, journals, articles and books, etc.

\section{The Trend of Methodology}

As noted in the preceding discussion, the translation of the Bible was based on the account of the missionaries' insensitive attitude toward the Africans. Mother-tongue hermeneutics which became the new way of translating the Bible from its original language context to the readers' language context seems to have been conceived long ago. This could be inferred from the assertion of Ukpong that:

"Africa can rightly be referred to as the cradle of systematic biblical interpretation in Christianity. The earliest of such an attempt can be traced to the city of Alexandria and to such names as Clement of Alexandria, Origin, and others who

\footnotetext{
23 John David Kwamena Ekem, Early Scriptures of the Gold Coast (Ghana) (Rome/Manchester: Edizioni Di Storia Eletteratura/St Jerome Publishing, 2011), xvii.

24 Philip Jenkins, The New Faces of Christianity: Believing the Bible in the Global South (New York: USA; Oxford University Press, 2006 ), 5.

25 Kwabena Asamoah-Gyadu ed. Trinity Journal of Church and Theology (Legon: Accra: Trinity Theological Seminary, 2005 ), 52.

Asamoah-Gyadu ed. Trinity Journal of church and theology, 52.

Asamoah-Gyadu ed. Trinity Journal of Church and Theology, 52.

Asamoah-Gyadu ed. Trinity Journal of Church and Theology, 53.

Asamoah-Gyadu ed. Trinity Journal of Church and Theology, 53.

Emmanuel Asante, Culture, Politics and Development: Ethical and theological Reflections on the Ghanaian Experience (Accra: Ghana; SonLife Press, 2007), 22 .

31 Lamin Sanneh, The Message: The Missionary Impacts on Culture Revised and Expanded (Maryknoll; NewYork: Orbis Books, 2009 ), 8.

32 Gillian M. Bediako ed., Journal of African Christian Thought: Biblical Exegesis in African perspective, Vol. 6. No.1 June (Akropong-Akuapem:AkrofiChristaller Memorial Centre, 2003), 1.
} 
lived and worked there. ${ }^{33}$ This is an indication that Africans were at the forefront of translation work for a much longer period. 'The foundation laid by this tradition, which was largely allegorical and uncritical in the modern sense, lasted in the Western Church till the onset of the Enlightenment. ${ }^{34}$ Thus, even though their work was relevant at the time it was introduced it ended at a point in the course of time. The period of enlightenment was 'replaced by the historical-critical method in the $18^{\text {th }}$ century followed by the literary approaches in the $20^{\text {th }}$ century. These methods, developed in the West, have today been well established and recognized as veritable scientific tools of modern biblical research. ${ }^{35}$ The above quotation pointed out that a method was developed to be the standard of translation and interpretation. Though Ukpong sought to situate the discussion on the method within Africa South, he then extended it to the entire Africa. That the impacts of the scientific tools were felt about in the middle of the $20^{\text {th }}$ century. ${ }^{36}$ Then he proceeded by stating that 'Biblical scholars in Africa have been able to develop a parallel method of their own. The particular characteristic of this method is the concern to create an encounter between text and the African context. ${ }^{37}$ The method is believed to 'involve a variety of ways that link the biblical text to the African context such that the main focus of interpretation is on the communities that receive the text rather than on those that produced it or on the text itself, as is the case with the Western methods. ${ }^{38}$

Ukpong expressed his interest in the period of which a method of interpretation lasted based on what Erickson referred to as 'brief life spans of theologies. ${ }^{39}$ Ukpong divided the period of the development of biblical interpretation in Africa into three phases. He referred to Phase I (1930s-70s) as a 'reactive and apologetic phase, focused on legitimizing African religion and culture, dominated by the comparative method. ${ }^{\prime 40}$ After that, he designated 'Phase II (1970s-90s) as a reactive-proactive phase with the use of African context as a source for biblical interpretation, dominated by liberation and inculturation-evaluative method and liberation hermeneutics (black theology). ${ }^{41}$

'Phase III (the 1990s) was described as the proactive recognition of ordinary readers in the African context as a subject of biblical interpretation, dominated by liberation and inculturation methodologies. ${ }^{42}$

In view of the above, one can situate the method of mother tongue hermeneutics in the third phase (the 1990s) looking at the period where Ekem and Laryea were contending for mother-tongue hermeneutics. Ekem argued that with particular reference to African communities, it was vital to provide study Bibles and commentaries that clearly articulated theological, linguistic and anthropological issues in the people's own local languages ${ }^{43}$ It is argued that Mother-tongue biblical studies use eclectic methodology. It borrows from the fields of Biblical Studies, Bible Translation Studies, and Language Studies - Biblical Languages: Ancient Hebrew/Aramaic and Greek, and Local African/Ghanaian Languages ${ }^{44}$ Based on this, one can refer to the methodology of mother-tongue hermeneutics as a complex process of doing an interpretation.

It is required in this methodology to first of all, 'identify a Biblical text which you think has been wrongly translated into your mother tongue. That is followed by providing the reason why the translation is problematic in your culture. ${ }^{45}$ Thereafter, the exegetes must state and explain the methodology he or she will use, and the proponents.' The exegete proceeds to 'do a study (an exegesis) of that text, using Bible Study resources - Dictionaries, Commentaries, Encyclopaedias, Word Study that helps, etc. and finds out what scholars have said about the text, how they interpret it and reasons for their interpretations. The next thing to do is to 'discuss the usage of the concept in one's language/ culture; interview indigenous speakers of his/her mother-tongue for deeper insights into the concept being researched. Use local terminologies in writing and explain them in English. Then the exegete should 'compare the text in his/her mother-tongue with other Ghanaian translations he or she can read and understand'. It must be followed by an analysis of the mother tongue-translations; what do they mean? How are the meanings of the text similar to that of Hebrew/ Greek? How are they different? What might have accounted for the differences in translation? ${ }^{46}$ Finally, the exegete must come out with a new translation of the text that fits into his/her culture. ${ }^{47}$ Even though this method is a tedious process for Bible translation, yet some people find it convenient to engage translation by using it to make the text relevant to the local language readers.

\footnotetext{
33 Ukpong, Developments in Biblical interpretation in Africa, 12.

34 Ukpong, Developments in Biblical interpretation in Africa, 12.

35 Ukpong, Developments in Biblical interpretation in Africa, 12.

36 Ukpong, Developments in Biblical interpretation in Africa, 12.

37 Ukpong, Developments in Biblical interpretation in Africa, 12.

38 Ukpong, Developments in Biblical interpretation in Africa, s12.

39 Millard J. Erickson, Christian Theology 2 ${ }^{\text {nd }}$. (Grand Rapids: UAS; Baker Books,2000), 63.

40 Ukpong, Developments in Biblical interpretation in Africa, 12.

41 Ukpong, Developments in Biblical interpretation in Africa, 12.

42 Ukpong, Developments in Biblical interpretation in Africa, 12.

43 Ekem, Priesthood in Context, 188.

44 Kuwornu-Adjaottor Mother-Tongue Biblical Hermeneutics, 577

45 Kuwornu-Adjaottor Mother-Tongue Biblical Hermeneutics, 577

46 Kuwornu-Adjaottor Mother-Tongue Biblical Hermeneutics, 577 .

47 Kuwornu-Adjaottor Mother-Tongue Biblical Hermeneutics, 577.
} 


\section{Current Products of Mother-Tongue Hermeneutics in Ghana}

Part of the effects of Mother-Tongue hermeneutics in Christianity is the upbringing of the biblical scholars. It is remarked that 'the outstanding biblical scholars in Ghana currently, who use the third cluster of doing biblical studies, that is "those - locate the meaning of the given text in the world in front of the text further is David Ekem." 48 This means that out of the three main methodological processes which were proposed by Tate namely the world behind the text, the world within the text and the world in front of the text. ${ }^{49}$ Ekem has proposed that the varied mother tongues of Africa have a lot to offer by way of biblical interpretation in Ghanaian/African languages as a viable material for interpretation, study Bibles and commentaries. ${ }^{50}$ Fortunately, in order not to invent the wheel or fabricate data for this sensitive area of this paper, the author sides with Kuwornu- Adjaottor to maintain that there are 'examples of publications in which mother-tongue biblical studies appear. ${ }^{{ }^{51}}$ Kuwornu-Adjaottor further outlines the following authors with their works as at the time he published the article on Mother-Tongue Biblical Hermeneutics in 2012. In this article, he listed the following publications in the field.

(a) (1) J. D. K. Ekem, "The Use of Archierus 'High Priest' as a Christological Title: A Ghanaian Case Study." Trinity Journal of Church and Theology Volume XI. Numbers 1 \& 2. 2001: 57-64.

(2) . "Translating Asham (Isaiah 53:10) in the Context of the Abura-Mfantse Sacrificial Thought." Trinity Journal of Church and Theology. Volume XII. Numbers 1 \& 2. 2002: 23-29.

(3) "Biblical Exegesis in an African context: Some Reflections." Journal of African Christian Thought Volume 6, No. 1 June 2003: 31-34.

(4) "Interpreting 'The Lord's Prayer' in the context of Ghanaian Mother-tongue Hermeneutics," Journal of African Christian Thought Volume 10. No. 2, December 2007:48-52.

(5) "Spiritual Gifts or Spiritual Persons?: 1 Corinthians 12:1a Revisited, Neotestamentica, Journal of the New Testament Society of South Africa 38. 2004 (1): 54- 74.

(6) _. New Testament Concepts of Atonement in an African Pluralistic Setting. Accra:SonLife Press. 2005.

(7) “ "Interpreting 'The Lord's Prayer' in the context of Ghanaian Mother-tongue Hermeneutics, ”Journal of African Christian Thought Volume 10.No. 2, December 2007:48-52.

(8) _ “A Dialogical Exegesis of Romans 3:2a, Journal of the Study of the New Testament (30) 2007:7593.

(9) Priesthood in Context: A Study of Priesthood in Some Christian and Primal Communities of Ghana and its Relevance for Mother-Tongue Biblical Interpretation. Accra: SonLife Press, 2008.

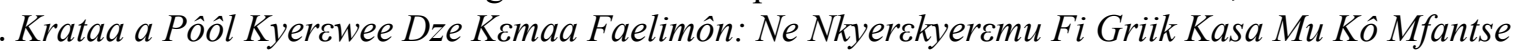
Kasa Mu. (A Commentary on Paul's Letter to Philemon Based on the Greek Text in Fante) Accra: SonLife Press. 2009.

(b) (1) J. E. T. Kuwornu-Adjaottor, "Are Sins Forgiven or Loaned? Translations and Interpretations of Matthew 6:12 by Some Dangme Scholars," ORITA: Ibadan Journal of Religious Studies. University of Ibadan Publication, XLII/2, December 2010: 67-81.

(2) "A comparative study of Matthew 6:12 and its parallel in some Ghanaian mother tongue translations of the Bible; in Proceedings of International Conference on Research and Development, Vol. 3, No. 4, ed., Freda M. Nekang, Accra: Pan-African Book Company, 2010:62-66.

(3) ."Interpretations of mias gunaikos andra (1Tim. 3:2a) in some Ghanaian mother- tongue translations of the Bible," Journal of African Biblical Studies, Ghana Association of Biblical Exegetes (GABES) Publication. Vol.3, January 2011, ISSN 0855773X, 43-61.

(4) "A Comparative Study of Mark 1:12 in Some Ghanaian Mother-tongue Translations of the Bible," Journal of Arts and Culture Volume 6, (1) November 2011, Duncan Science Company Publication, ISSN: 2006 1145: 67-73.

(5) E. N. B. Anum \& J. E. T. Kuwornu-Adjaottor, "New Testament Concepts of Forgiveness in the Gospels in the Context of the Dangme Translation and Usage," American Journal of Biblical Theology, Vol. 12 (25), 2011: 1-19.

(c) (1) P. T. Laryea, "Reading Acts 14:8-17 and 17:2231 in Gā: A Critical Examination of the Issues, Meanings and Interpretations Arising from the Exegesis in the Mother Tongue." Journal of African Christian Thought Volume 5, Number 1, June 2002: 35-43.

\footnotetext{
48 Kuwornu-Adjaottor Mother-Tongue Biblical Hermeneutics, 577.

49 W. Randolph Tate, Biblical Interpretation: An Integrated Approach 3rd edition (Grand Rapids: U S A: Baker Academic, 2008 ), $11,89,189$.

50 Kuwornu-Adjaottor Mother-Tongue Biblical Hermeneutics, 577.

51 Kuwornu-Adjaottor Mother-Tongue Biblical Hermeneutics, 577.
} 
Theses in the Area of Mother-Tongue Biblical Studies

The following are Master of Theology theses in the area of Mother-Tongue Biblical Studies, supervised by J. D. K. Ekem, Director of the Institute of Mother Tongue Biblical Hermeneutics, Trinity Theological Seminary, Legon, Ghana.

(1) J.E.T. Kuwornu-Adjaottor, Some Translation and Exegetical Problems in the Dangme New Testament. 2. 2007.

(2) Frederick Amevenku, An Ewe Interpretation of the use of 'Logos' in John's Gospel: A case for Mother-Tongue Hermeneutics,3. 2008.

(3) Seth Kissi, An Akan View of Jesus: Exegetical Exploration into Hebrews 1:1-14 in the light of Insights from Akan Mother Tongue. 4. 2009,

(4) Frimpong Wiafe, Syntactical Analysis, Morphology and Theology of Genesis 1:110, 26-31: Implications for Asante-Twi Mother-Tongue Hermeneutics. 5. 2009.

(5) John Fosu, Paul's response to the abuse of Spiritual gifts in the Corinthian Church (1Corinthians 12-14): Lessons for the Ghanaian context. 6. 2012,

(6) J. E. T. Kuwornu-Adjaottor, MotherTongue Bibles, Resources for African Biblical Studies, PhD Thesis (by Publication) submitted to the School of Graduate Studies and Research, Kwame Nkrumah University of Science and Technology, Kumasi, Ghana. ${ }^{52}$

Besides those mentioned above, there is also a thesis that was supervised by Rev. Prof. Gilbert Ansre in the Mother Tongue Hermeneutics undertaken by Livingstone Yao Torsu entitled Translating Shalom and Its Derivatives in the Old Testament: A Study of Aspects of Semantic Differentiations and their Implications for Translating into Ewe and English Accra: Ghana; Trinity Theological Seminary, 2015.

\section{Reflection}

Though it appears that not many of the current Biblical scholars are enthused about this area of translation, few who find it very interesting are making great strides and their efforts are yielding good results. To some people, mother tongue hermeneutics is only an academic exercise, but to the large extent, such impressions appear erroneous. Because through this enterprise, many local Bible versions are being revised to address current quests for readers, it can be stated here that, mother-tongue hermeneutics is addressing not only the quest of the readers to gain more understanding in their native tongues but it also deepening the faith of the believers especially, the Christian community because it is making the Bible friendly to the local readers and hearers. Beyond being a friendly reception to the local readers and hearers, it also serves as evangelistic material for both literate and illiterates. That means with the help of mother tongue hermeneutics evangelism becomes easy for everyone. This implies that by the work of mother-tongue hermeneutics, the message of the Bible is carried out by both literates and illiterates to other literates and illiterates alike.

Mother-tongue hermeneutics has become the magnetic force that makes the message of the Bible attract everyone in every context both in Africa and beyond because it is a translation procedure that lays emphasis on contextsensitive translation. From this context-sensitivity, the magnetic force is derived, particularly from the culture of the people to whom the message has come. The role of culture is important in Christian mission. Thus, culture is one of the major tools to be considered in terms of aiming at expanding the work of Christianity. ${ }^{53}$ The importance of culture to the translation within the scope of mother tongue hermeneutics is echoed in the words of Sanneh.

He avers that,

'for the early Christians, there were two basic ways to proceed. One was to make missionary culture --in their case, the Mosaic code---the carrier and arbiter of the message. This we might call mission by diffusion. By it, religion expands through its founding cultural warrants and is implanted in other societies primarily a matter of cultural adoption. The other way was to institute the recipient culture as a valid and necessary locus of the proclamation, allowing the religion to arrive without the requirement of deference to the originating culture. This we might call mission by translation. ${ }^{54}$

Getting the idea promulgated by Sanneh reveals that mother-tongue hermeneutics was foreseen long ago to be the vehicle to convey the biblical message across the boundaries with the help of culture. It has also been identified that the only way a religion like Christianity can be expanded is through context-sensitive translation which is the work of mother tongue hermeneutics.

\section{CONCLUSION}

It has been discovered that the effect of Mother-tongue hermeneutics in Christianity is varied and enormous. For it

\footnotetext{
52 Kuwornu-Adjaottor, Mother-Tongue Biblical Hermeneutics, 577.

53 Livingstone Y.Torsu, \& Francis Brown, Jesus and Ethnicity: A Theological Reflection on the Message of John 4:1-24, Pentecostalism, Charismaticism and Neo-Prophetic Movements Journal Vol.1 No.3 (2020): 41 - 49.

${ }^{54}$ Sanneh, Translating The Message,33.
} 
comes up clearly that mother-tongue hermeneutics has contributed to the growth of Christianity in Africa particularly Ghana in the areas of church establishment and growth of African Independence Churches. Mother-tongue hermeneutics has become a means by which the faith of the local people is grown. As a result of this trend, local preachers are produced to lead the churches. Since there is the need for more materials to be read, scholars are produced to take up the responsibility to work on documents like local language commentaries, local language Bibles, articles articulating the possible renditions, journal contesting for readers' worldview to be considered in the translation of the Biblical text, etc.

Besides, it has been observed that mother tongue hermeneutics preserves and creates the culture of the people involved. This means mother-tongue hermeneutics has placed great value on the readers' culture and language in order that people can be proud and sustained. Mother-tongue hermeneutics enables local people to identify themselves with the Bible because of the local language used to translate the Bible from the Hebrew and Greek languages. This behavior of the local people can be related to the experience of people who witnessed the day of Pentecost as they began to understand the concept of messages given by the disciples in their own languages as stated in Acts 2:1-6. If mothertongue hermeneutics preserves and creates current culture, then it presupposes that the neglect for learning and teaching the language will be the end of African culture relevance. Thus, the need to promote culture is by way of encouraging translation works particularly Biblical translation so those cultural identities are not destroyed.

The importance of this study cannot be downplayed because if the great commission has to be realized, then there is the need for mother-tongue commentaries, files and books, journals and articles. It should be seen as a requirement for experienced scholars in the field to encourage the up-and-coming students to have an interest in the fields of translation. Most especially those who find their way into the field of Biblical studies must be encouraged to take the translation course work seriously so that they do not only spread the Christian faith but to also sustain the faith and indigenous churches as well as increase the confidence level of the local preachers and their hearers.

\section{ABOUT AUTHOR}

Livingstone Yao Torsu is a Lecturer in the Department of Theology, Heritage Christian College, Accra- Ghana.

\section{BIBLIOGRAPHY}

Amonoo, R. F. Language and Nationhood: Reflections on Language Situations with Particular Reference to Ghana The J. B. Danquah Memorial Lectures Series 19, February 1986. Accra: Ghana Academy of Arts and Sciences, 1989.

Asamoah-Gyadu, K ed. Trinity Journal of Church and Theology. Legon: Accra: Trinity Theological Seminary, 2005.

Asante, E. Culture, Politics and Development: Ethical and theological Reflections on the Ghanaian Experience. Accra: Ghana; SonLife Press, 2007.

Bediako M. G. ed., Journal of African Christian Thought: Biblical Exegesis in African Perspective, Vol. 6.No.1 June. Akropong-Akuapem:Akrofi-Christaller Memorial Centre, 2003.

Ekem, J.D.K. Early scriptures of the Gold Coast (Ghana). Rome/Manchester: Edizioni Di Storia Eletteratura/St Jerome Publishing, 2011.

Ekem, J.D.K., Priesthood in Context: A Study of Priesthood in Some Christian and Primal Communities of Ghana and its Relevance for Mother-Tongue Biblical Interpretation. Accra: SonLife Press, 2008.

Erickson, J.M. Christian Theology $2^{\text {nd }}$. Grand Rapids: UAS; Baker Books,2000.

Jenkins P. The New Faces of Christianity: Believing the Bible in the Global South. New York: USA; Oxford University Press, 2006.

Kuwornu-Adjaottor J. E. T., Mother-Tongue Biblical Hermeneutics: A Current Trend in Biblical Studies in Ghana. Journal of Emerging Trends in Educational Research and Policy Studies (JETERAPS) 3 no.4 (2012), 575-579.

Miller D., The correlates of entrepreneurship in three types of firms. Management Science, 29, (1983):770-791.

Okpara F. O., The Value of Creativity and Innovation in Entrepreneurship. Journal of Asia Entrepreneurship and Sustainability, 3, no. 2, (2007): 1.

Sanneh L. Translating The Message: The Missionary Impacts on Culture Revised and Expanded. Maryknoll; New York: Orbis Books, 2009.

Quarshie B.Y., "Doing Biblical Studies in the African Context - The Challenge of Mother-tongue Scriptures," Journal of African Christian Thought, 5, no 1, (2002): 4-14.

Tate, W. R. Biblical Interpretation: An Integrated Approach $3^{\text {rd }}$ edition. Grand Rapids: USA: Baker Academic, 2008. 
Torsu, L.Y., \& Brown, F. Jesus and Ethnicity: A Theological Reflection on the Message of John 4:1-24, Pentecostalism, Charismaticism and Neo-Prophetic Movements Journal Vol.1 No.3 (2020):41 - 49.

https://doi.org/10.38159/pecanep.2020081

Ukpong, J. S. Developments in Biblical Interpretation in Africa: Historical and Hermeneutical directions. In Gerald O. West and Musa W. Dube eds. The Bible in Africa: Transactions, Trajectories and Trends (Leiden-Boston-Koln; Brill, 2000. 